\title{
ATTITUDES TO OTHERNESS: CZECH ONLINE SURVEY
}

Nikola Minarčíková ${ }^{1,2}$

nikola.minarcikova@nudz.cz
Martina Barcaj ${ }^{1}$
Veronika Juríčkovái
Marek Preiss ${ }^{1,4}$

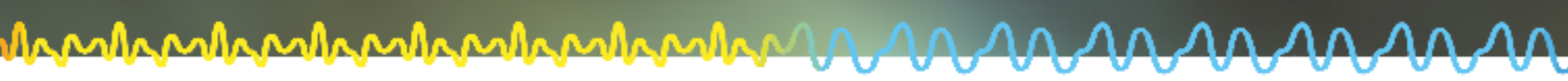

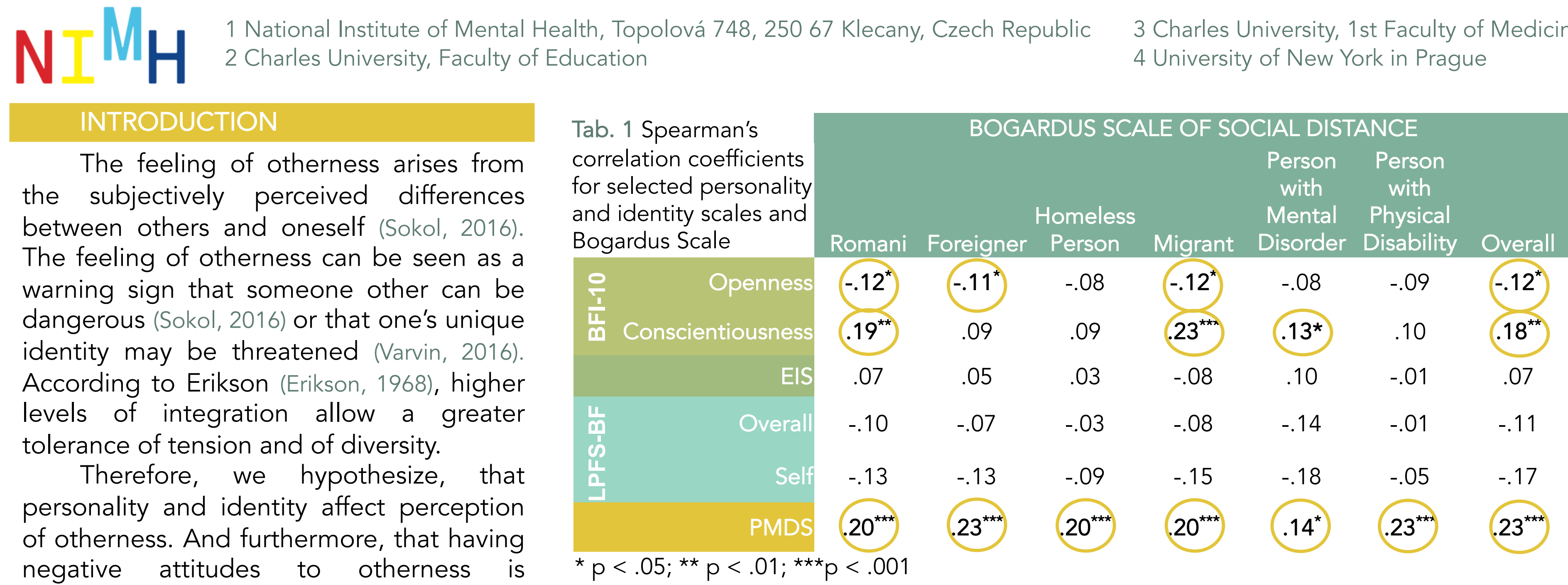

\section{METHODS}

Big Five Inventory-10 (BFI-10) (Rammstedt \& John, 2007)

Ego Identity Scale (EIS) (Tan et al., 1977)

Level of Personality Functioning Scale Brief Form (LPFS-BF) (Bach \& Hutsebaut, 2018)

Propensity to Moral Disengagement Scale (PMDS) (Moore et al., 2012)

Bogardus Scale of Social Distance (Bogardus, 1947) Romani, Foreigner, Homeless Person, Migrant, Person with Mental Disorder, Person with Physical Disability as representatives of otherness.
Fig. 1 Relationship between personality and identity measures and overall Bogardus Scale of Social Distance score.

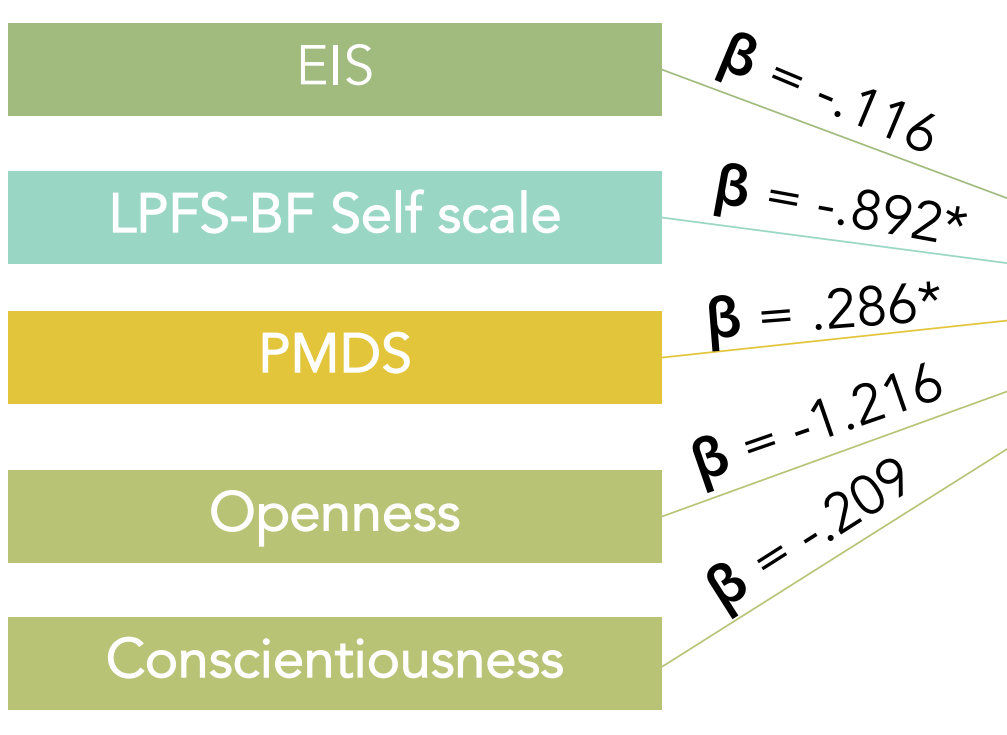

$\mathrm{R}^{2}=.113$ $* p<.05$

Overall Score Bogardus Scale of Social Distance

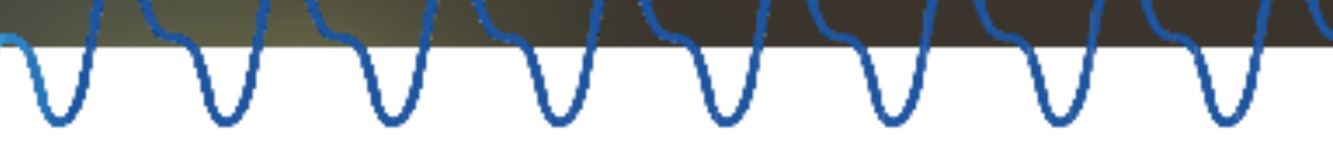

\begin{tabular}{|c|c|c|}
\hline \multicolumn{3}{|c|}{ PARTICIPANTS } \\
\hline$N$ & Age & Gender (M : F) \\
\hline 260 & $19-55$ & $95: 165$ \\
\hline & $(M=27.45, S D=6.66)$ & 9 \\
\hline
\end{tabular}

General population sample recruited via posts on social media.

\section{RESULTS}

Spearman's correlation analysis was conducted to assess the relationship of the Bogardus Scale and personality and identity measures and moral disengagement (Tab. 1).

Multilevel regression analysis predicting overall score of Bogardus Scale was run. Model with the best fit explains $11.3 \%$ of the variability (Fig. 1).

\section{CONCLUSION}

We hypothesized, the more insecure is one's identity, the more of a threat is someone who is perceived as a representative of otherness. Unfortunately, the results showing the association between attitudes to otherness and identity are not clear. Our assumption that claiming larger social distance is somehow reprehensible seems to be in line with the results. People who maintain larger social distance are more prone to mora disengagement. Also, larger social distance is maintained by people with low Openness to Experience and high Consciousness.
Bach, B., \& Hutsebaut, J. (2018). Level of Personality Functioning Scale-Brief Form 2.0: Utility in Capturing Personality Problems in Psychiatric Outpatients and Incarcerated Addicts. J Pers Assess, 1-11. Bogarous, E. S. (1947). Measurement of Personal-Group Relations. Sociometry, (4), 306.

Erikson, E. H. (1968). Identity: youth and crisis. New York: Norton.
Moore, C. et al. (2012). Why Employees Do Bad Things: Moral Disengagement and Unethical Organizational Behavior. Pers Psychol, 65(1), 1-48.

Rammstedt, B., \& John, O. P. (2007). Measuring Personality in One Minute or Less: A 10-item Short Version of the Big Five Inventory in English and German. J Res Pers, 41(1), 203-212.

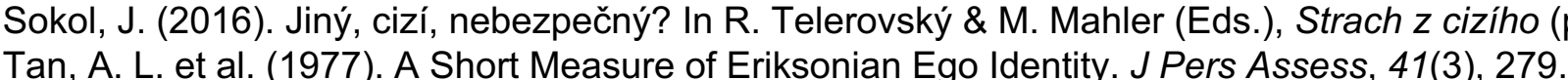

Varvin, S. (2016). Tolerance k cizincưm: 'Čí je to domov?' In R. Telerovský \& M. Mahler (Eds.), Strach z cizího (pp. 169-178). Praha: Česká psychoanalytická společnost.
ACKNOWLEDGEMENTS This study is a result of the research funded by the Czech Science Foundation, grant nr. 19-10057S, and by the project nr. L01611 with a financial 